\title{
The Warsaw-Bucharest axis and Romania's place in the Three Seas Initiative? Polish-Romanian Leadership in the Three Seas Initiative (3SI)
}

\section{Introduction}

The collapse of the bipolar world unleashed the sovereignty potential of Central and Eastern European states. The polarization of the international order is now intensifying, a fact strongly felt primarily by small sovereign states, forced to take sides. In this instance, regional initiatives are being launched to maintain the existing international order for as long as possible. Why the existing order? The existing order is the most advantageous for post-communist countries, as they are constantly working out their place in the structure of international order.

This article presents the role of Romania and Poland in the Three Seas Initiative (3SI). The central issue, however, is to define Romania's role in the 3SI. In order to develop this issue, specific problems are used in the form of explaining what the 3SI is, what the geopolitical significance of Romania in the 3SI is, what Romania's vision of the 3SI format is, what Romania's contribution is, especially by the Bucharest summit, to shaping the 3SI development strategy. Particular issues are discussed on the basis of the Polish case literature to highlight the Polish vision of Romania's role in the 3SI.

In order to meet the above objectives, a number of research methods were employed. First and foremost, systemic analysis was applied, recognizing the 3SI as a system of mutual Polish-Romanian relations, ties and interests. The overall approach was further expanded by introducing a geopolitical paradigm.

\section{The 3SI concept}

The 3SI is an idea of regional cooperation of Central European countries. The name Three Seas comes from the stretching of the area between the Baltic, Black and Adriatic 
Seas. In Poland, this area is known as the Intermarium ${ }^{1}$ and relates to the idea of cooperation between the countries of the region since the interwar period ${ }^{2}$.

The 3SI was launched by Poland and Croatia in 2016. The 3SI consisted of Austria, Bulgaria, Croatia, Czech Republic, Estonia, Hungary, Latvia, Lithuania, Poland, Romania, Slovakia, and Slovenia. The 3SI's primary tasks are to foster cooperation between the states within the EU structures, strengthen relations with the U.S., and reinforce infrastructure, energy, and cybersecurity initiatives.

Due to the manifold differences in the perception of the 3SI, it has not been decided to institutionalize it insofar. The whole project is coordinated through summits of state presidents. Notably, the 3 SI is not an international organization but only a platform for cooperation. Considering the whole project and the divergent interests of the states, the 3SI "summit diplomacy" format is the best quasi-institutional solution for the CEE states $^{3}$.

\section{Geopolitical significance of Romania}

Romania wields geostrategic importance due to its location by the Black Sea. It is located at the crossroads of Orthodox, Turkish and Western civilizational and cultural domains. Romania's geopolitical location is a clear advantage, which the Bucharest government is trying to leverage in its image. First of all, the country influences politics in the Balkans, as well as politics within the Black Sea.

Romania's territory includes the Danube delta, one of the longest rivers in Europe interconnecting countries such as Serbia, Croatia, Hungary, and Austria. As a result, Romania is driven to close cooperation in terms of inland transportation and trade. In addition, Romania owns a few port cities: Constance, Galatz, Braila. All the advantages of Russia's geopolitical location have been recognized by the EU and embraced in the Danube Strategy (EU Strategy for the Danube Region) ${ }^{4}$, an EU agenda adopted by the European Commission in 2010.

Romania sits on the energy trail. For EU energy security projects, Romania is in a strategic position due to its Caspian policy and transport routes. Since the late 1990s and the turn of the century, a number of infrastructure projects of strategic importance for energy security have been built. Romania plays an important role as a transit corridor linking Black Sea and Caspian Sea interests, such as Nabucco, Constanta-Trieste, AMBO (Albania Macedonia Bulgaria Oli), White Stream, INOGATE, TRACECA. In order to boost energy and transport cooperation, the Craiova Group bringing together Bulgaria, Romania and Serbia was established in 2015.

M. J. Chodakiewicz, Międzymorze, Warsaw 2016, p. 610.

2 P. Lewandowski, Geopolitical Ideas of Great Space as Soft Power-Analysis of the Case of the Republic of Poland, "The Bellona Quarterly" 2019, no. 698/3, pp. 59-80.

3 B. Surmacz, Dyplomacja na szczycie, “TEKA of Political Science and International Relations” 2016, no. 11/3, pp. 95-109.

4 EU Strategy for the Danube Region, https://danube-region.eu/, access 15 VI 2021. 
Poland perceives Romania as the southern leader of the CEE region. Romania is appreciated for its active international policy. As for its geopolitical importance, its good relations with Bulgaria (with which it forms NATO's eastern flank) are accentuated. Romania has good relations with Serbia, mainly because the Romanian side does not support Kosovo's aspirations for independence. Romania has constantly indicated and supported the Serbian side in its aspirations for integration into the $\mathrm{EU}^{5}$. Romania has good historical and political relations with Poland, dating back to the period prior to World War II ${ }^{6}$. Negative relations with Hungary are caused by the Hungarian diaspora in Transylvania. As for relations with Ukraine, they have evolved considerably. Before the Ukrainian-Russian war, Romania had several contentious issues with Ukraine: minority issues, territorial disputes, and Romanian-Moldavian relations. After the war, there was a sobering of Bucharest's vision of a real threat and a perception of Ukraine as an ally ${ }^{7}$.

\section{Romania and the Three Seas}

The beginning of the 3SI initiative promised to be rather vague and uncertain. First of all, a number of political problems between the CEEC states were put forward. A series of irregular bilateral and multilateral relations between the states of the region were indicated. Since the very beginning of the 3SI, Romania has been considered as one of the CEE leaders. First of all, points are made to its economic potential (economic growth of recent years), demographic potential (still high despite the problem of migration of young people), intensive and independent policy in the region.

Similarly to Poland, Romania is considered to be a leader in the CEE region, and thus also among the 3SI states. Initially, Romania was quite cautious about the initiative. This can be seen after the participation in the first 3SI summit in Dubrovnik, where the Romanian side was represented by Petru Sorin Buse, Minister of Transport ${ }^{8}$. This meant that Romania clearly indicated the nature of the initiative as a project of economic and infrastructural importance.

The Dubrovnik Declaration met the expectations of the Romanian side. The issues of political cooperation were almost entirely rejected (in order not to raise doubts with the EU and Russia). Three main pillars of cooperation were adopted: infrastructure and economy, energy, and digital communication ${ }^{9}$. In terms of political cooperation, there

5 M. Skrzeszewska, Droga Serbii do Unii Europejskiej - stan i perspektywy, "Studia Europejskie" 2016, no. 1, p. 137-163.

6 K. Kotulewicz-Wisińska, Stosunki polsko-rumuńskie w latach 2009-2017. Wybrane problemy, "Krakowskie Studia Małopolskie" 2018, no. 23, p. 142.

7 P. Ukielski, Mapa Trójmorza. Przegląd punktów wspólnych i rozbieżności w polityce 12 państw regionu, "Raport" 2016, no. 3, p. 26.

8 P. Kowal, A. Orzelska-Stączek, Inicjatywa Trójmorza: geneza, cele i funkcjonowanie, Warsaw 2019, p. 56.

9 Wspólna deklaracja w sprawie Inicjatywy Trójmorza, https://www.prezydent.pl/aktualnosci/wizytyzagraniczne/art,105,wspolna-deklaracja-w-sprawie-inicjatywy-trojmorza.html, access 15 VI 2021. 
was a declaration of gaining external support for the entire project, understood as an inflow of investment and funds.

Probably after the first summit in 2016, Romania shifted the perception of the 3SI. First of all, the summits were attended by representatives of the US and China (Dubrovnik). The 2nd 2017 summit was attended by President Donald Trump. Solely the Czech Republic and Austria were not represented by heads of state. In late 2016 and early 2017, the Romanian side saw the integration potential of the 3SI and the opportunity to pursue its own interests in the region along with raising its prestige. This is also where the direct narrowing of the 3SI's cooperation with the US comes in. The idea of inviting representatives of China and Turkey was abandoned.

The 3rd 2018 Bucharest 3SI summit was designed to serve the above purpose. The summit also revealed the involvement of regional countries. Only the Czech Republic, Estonia and Latvia were represented by presidents of parliament or a minister.

The evolution of Romania's mindset on the $3 \mathrm{SI}$ is evident. The Romanian side has made it no secret that it makes its commitment to the initiative contingent on the realization of its geostrategic vision by way of U.S. support for the whole endeavor ${ }^{10}$. Romania works much more intensively with extra-regional partners. Romania's growth strategy pertains through its involvement in cooperation with the most important European players: the UK, France, Germany, and Italy. The 3SI nations do not ensure Romania gets what it seeks; an inflow of investor capital and stabilization of security in the region along with support for its Black Sea plans. Relations with neighbors, although correct, play a secondary role ${ }^{11}$.

\section{The importance of the Bucharest summit for Romania's foreign policy}

At the Bucharest summit, two ideas, two visions of CEE development from the perspective of transatlantic and post-Atlantic cooperation grappled with each other ${ }^{12}$. The Polish side expressed a vision of tightening cooperation with the U.S. The Romanian side invited the German representative Heiko Massa, who spoke about a new world order and a new EU and CEE order. He proposed increasing Germany's involvement in the 3SI and suggested working out a new dialogue framework with Russia ${ }^{13}$.

The head of the European Commission and the heads of the European Bank for Reconstruction and Development and the European Investment Bank also attended the summit. The President of Romania, Klaus Werner Iohannis, and Jean-Claude Juncker supported Germany's position on joining the 3SI. However, Romanian actions were

10 M. Dobija, Geopolityczne czynniki innowacyjnego rozwoju Polski i krajów Trójmorza, "Nierówności Społeczne a Wzrost Gospodarczy” 2019, no. 59, p. 45.

11 J. Pieńkowski, Polityka europejska Rumunii, “Biuletyn Polskiego Instytutu Spraw Międzynarodowych” 2017, no. 99, p. 2.

12 P. Kowal, A. Orzelska-Strączek, op. cit., p. 67.

13 L. Sykulski, Trójmorze w świecie wielobiegunowym, "Myśl suwerenna. Przegląd spraw publicznych" 2020, no. 2, pp. 20-21. 
not reflected in the Bucharest Summit Joint Declaration ${ }^{14}$. In it, three main objectives of co-operation were recognized: economic advancement of the states in the region, strengthening of convergence within the $\mathrm{EU}$, and reinforcement of transatlantic ties.

There is a clear rift between the interests of Romania and Poland, the two informal 3SI leaders ${ }^{15}$. At the Bucharest summit, Poland was represented by President Duda, replaced by Prime Minister Mateusz Morawiecki during the second day of the summit. At that time, President Duda paid a visit to Washington as an emissary of the 3SI. A strong transatlantic option is apparent in the Bucharest Summit Joint Declaration in spite of Romania's own emphasis on closer cooperation with Germany ${ }^{16}$. Nevertheless, strategic cooperation with the U.S. in Romania has never been secondary. The search for new partners for the 3SI is one of the strategies of the Romanian side.

The Bucharest Summit was a turning point in the history of the 3SI and the countries' attitude to transatlantic cooperation. However, this case necessitates attention to the vision of economic cooperation of the states of the region with the US. In the whole document, the EU and the US are mentioned as partners five times and two times, respectively ${ }^{17}$. It is evident that the $3 \mathrm{SI}$ is seen as an area that complements and counterbalances the great-power policies of the US, China and Russia, opting unequivocally for cooperation with the West.

It was in Romania that the 3SI progressed from the conceptual stage to the level of working out goals, a common strategy, and seeing the entire initiative as a form of regional international security organization. In Romania, a Business Forum was organized, letters of intent and a Joint Statement for the creation of the 3SI Network of Chambers of Commerce were signed for the establishment of the 3SI Fund. For Romania, the Bucharest summit was a milestone in its engagement in the 3SI; the Polish side points out that "from this moment on in the development of the Three Seas, Bucharest has been striving to present to the public as the third driving force behind the Initiative (after the initiators, Croatia and Poland)"18.

Romania's trust and commitment to the $3 \mathrm{SI}$ and Poland is clear to see by their joint activities. The banks of both countries (Polish Bank Gospodarstwa Krajowego and Romanian EximBank) have established the 3SI Fund. Currently, the Fund holds nearly $€ 1$ billion ${ }^{19}$. Apart from Poland and Romania, Latvia and Estonia have joined the fund. It seems that Hungary, Bulgaria, Croatia and Slovenia will also become involved in the

14 P. Kowal, A. Orzelska-Strączek, op. cit., p. 67.

15 P. Lewandowski, Soft power Rzeczypospolitej w Inicjatywie Trójmorza, "Sprawy Międzynarodowe" 2020, no. 73(2), p. 144.

16 B. Wiśniewski, Szczyt Inicjatywy Trójmorza w Bukareszcie - wizja nabiera kształtu, https://pism.pl/, access 15 VI 2021.

17 Joint Declaration of the Third Summit of the Three Seas Initiative, http://three-seas.eu/jointdeclaration-of-the-third-summit-of-the-three-seas-initiative/

18 P. Ukielski, Inicjatywa Trójmorza w polskiej polityce zagranicznej, "Studia Europejskie" 2018, no. 2, p. 148.

19 J. M. Nowakowski, Trójmorzec czy Międzymorze, Warsaw 2020, p. 10. 
future. At the end of 2020, the United States transferred $\$ 300$ million to the Fund, as announced by Mike Pompeo ${ }^{20}$.

Romania's interest in the 3SI is rather explicit. Romania is experiencing one of the highest economic growth rates in the EU (around 4.7\%). Romania enjoys the advantages of low employment costs, large labor resources. In the face of the Covid pandemic, like other countries in the region, it hoped for the nearshoring of European countries' businesses from Chin $\mathrm{a}^{21}$. Hence, Romanian involvement in the $3 \mathrm{SI}$ is increasing.

\section{The Three Seas and Romania' s national security strategy}

In mid-2020, the Romanian Parliament approved a new "National Security Strategy" for the years 2020-2024. In fact, the strategy does not surprise nor does it introduce new solutions in terms of regional security and policy towards the region. Romania stresses the need to strengthen its position in the EU and NATO structures. This will certainly be the main responsibility of the new government of Florin Cîțu. With regard to the 3SI, it is clear that Romania is seeking to reinforce regional cooperation, mainly in the Balkans. In order to assert its role, it seeks to maintain a strategic partnership with the United States. Romania underlines its involvement in the Black Sea policy and strives to support the Black Sea and Western Balkan countries in their integration into European and Euro-Atlantic structures (e.g. through the Eastern Partnership) ${ }^{22}$.

The strategy clearly indicates Romania's orientation towards international affairs. Romania places emphasis on the priority role of the U.S. in the superpower rivalry. As for the 3SI, the format is meant to protect Romanian interests in the face of Chinese competition, as well as to build a stable regional system of technological cooperation notably on 5G. In this regard, Romania has discontinued cooperation with China on $5 \mathrm{G}$ network expansion. The $3 \mathrm{SI}$ is expected to become a platform to strengthen the U.S. position in competition with China and Russia. Romania is explicit in its support for upholding the current unilateral international order. This came about following the meeting between Presidents Trump and Iohannis in $2019^{23}$.

Romania defines the 3SI as an informal and flexible format with strong economic significance. However, a geopolitical aspect is also discernible in this interpretation; “The overarching pillars of the Three Seas Initiative are threefold - economic development, European cohesion, and transatlantic ties." ${ }^{24}$ Romania thus inscribes the 3 SI format as strengthening its role in EU structures and improving relations with the U.S. This is in line with the strategic objectives of the Romanian political elites (they demonstrate cross-party cohesion in this).

\footnotetext{
20 J. Wiech, Miliard dolarów na energetykę Trójmorza. Co kryje zapowiedź Mike’ a Pompeo?, https:// energetyka24.com/, access 15 VI 2021.

21 P. Nierada, Dokąd zmierza Trójmorze?, "Układ Sił” 2020, no. 23, p. 16.

22 K. Całus, Nowa strategia bezpieczeństwa Rumunii, https://www.osw.waw.pl/, access 15 VI 2021.

23 Ibidem.

24 The Three Seas Initiative (3SI), http://www.mae.ro/en/node/52671
} 


\section{The Warsaw-Bucharest Axis of Common Interest}

The Polish position within the 3SI cooperation is clear; a strategic partnership between Poland and Romania, the two largest countries in the region, will be indispensable for the success of the entire initiative in a broader sense than simply the U.S. strategy against China and Russia ${ }^{25}$. A significant strengthening of Polish-Romanian relations followed the 2009 declaration of the strategic partnership ${ }^{26}$. Due to the economic initiatives planned within the 3SI until 2027, the Polish position towards the East (Belarus and Ukraine) and Romania's position in the Balkans will be strengthened.

The Romanian authorities perceived the 3SI as a continuation of the Polish geopolitics of the Intermarium. There are many indications that Romanian politicians did not differentiate between the current concept of the 3SI and the previous ones. Both the Intermarium and the Three Seas were considered the same manifestation of Polish geopolitics. This created distrust among the Bucharest authorities ${ }^{27}$. The Romanian authorities' skepticism stemmed from their vision of institutionalizing the entire format. Initially, it was assumed that they would participate in the project only after its ideas were clarified or its first successes achieved.

The differences in Warsaw's and Bucharest perception of the Three Seas Initiative are minor. From the very beginning, the Romanian authorities underlined that they do not see the possibility of the $3 \mathrm{SI}$ becoming a counterweight to the EU. The Romanian authorities, primarily the president, who originates from the German minority, attaches great importance to regional and structural cooperation within the EU. He seeks to improve relations with Berlin, Paris, and Brussels. In 2017, President Iohannis indicated that Romania, together with other Western countries, will be the future driving force of the entire EU project. His plans are to strongly compensate the differences in terms of growth levels between Romania and the other EU member states.

In this challenge, Romania faces similar issues as Poland: a fall into the trap of average growth, and a need for investment in production and services. For this to happen, strong technological growth is required. Romania and Poland, as well as all CEE countries, are entering into technological competition ${ }^{28}$. The 3SI format and its cyber development aspect represent an opportunity to level the playing field for technological development.

By joining the 3SI, Romania opted for realism and pragmatism. The geopolitical location of the state also plays an important role. Due to its location, Romania has discovered the potential to benefit from all the projects carried out in the WestEast and North-South policies. Bucharest sees the prospect of developing initiatives as strengthening its international position. Romania is constantly in favor of EU

${ }_{25}$ K. Henning, Inicjatywa Trójmorza. Jeśli razem, to dokąd i jak?, Kraków 2018, p. 5.

26 K. Zubelewicz, Polska, "Europa Środkowo-Wschodnia" 2012, no. 19, p. 252.

27 O. Milewski, Trójmorze - nowy instrument w polskiej polityce zagranicznej, "Polski Przegląd Dyplomatyczny" 2017, no. 4, p. 57.

28 P. Grochmalski, P. Lewandowski, P. Paszak, US-China Technological Rivalry and its Implications for the Three Seas Initiative (3SI), "European Research Studies Journal” 2020, Special no. 2, pp. 840-853. 
membership expansion, and as a Black Sea country, it is eager to participate in all projects that underline its importance in the region.

In terms of security, Romania is much closer to Poland. Bucharest and Warsaw are interested in broadening and deepening cooperation within NATO and enhancing the role of the Black Sea and the Baltic Sea within the EU agenda ${ }^{29}$. In order to raise the rank and geopolitical importance of both countries and to elicit commitment on NATO, in 2015, Presidents Duda and Iohannis initiated the creation of a new format, the so-called Bucharest Nine (B9). The B9 is tasked with developing a new security platform within NATO on its eastern flank ${ }^{30}$. This followed Russian actions in the Black Sea basin. Poland and Romania perceive the Russian threat in the region in a comparable vein.

In this regard, the 3SI member states also represent a low potential in NATO's overall balance sheet in terms of military security. Despite the financial outlays of these states on the armed forces amounting to 2 percent, their real share is insignificant. Only Poland and Romania have armed forces that count towards the Alliance' $s$ total ${ }^{31}$.

Closer cooperation and improvement of Polish-Romanian relations are evident following a 2019 joint initiative, when, featuring, inter alia, Latvia and the Czech Republic, the Three Seas Investment Fund was established with an initial capital of EUR 500 million. Ultimately, the fund is to hold up to EUR 5 billion ${ }^{32}$.

Already in 2018, the ministers of transport from Poland, Bulgaria, Lithuania, Romania, Slovakia and Hungary filed a motion with the European Commission to include the Via Carpatia planned under the 3SI in the TEN-T core network. The construction of the said road is part of the development of North-South connections. The whole concept of the 3SI is invoked on this layout. The meridian development also constitutes an element of the Romanian strategy.

Closer institutional and governmental cooperation between Poland and Romania is expected to be a strategic challenge in the years to come. The cooperation between both governments has been proven by the Polish and Romanian business to be necessary to tighten economic contacts. The 2019 Polish-Romanian meeting made it possible to point out the milestones achieved to date. The most important ones included hosting the first Three Seas business forum in Bucharest, adopting the list of priority projects in there, creating the Three Seas fund and the CEE plus stock exchange index, setting up three working groups focused on infrastructure, energy, and digitalization. The overall Polish-Romanian cooperation is promoted as closing the development gap between the EU member states ${ }^{33}$. The CEE plus stock exchange index implies a joint listing of the

29 M. Mróz, Wielki projekt małych krajów. Od Międzymorza do Trójmorza w polityce zagranicznej Polski $w$ dobie drugiego rządu Prawa i Sprawiedliwości, "Dyplomacja i bezpieczeństwo" 2018, no. 5, p. 31.

30 A. Orzelska-Stączek, Inicjatywa Trójmorza w świetle teorii realizmu. Polityczne aspekty nowej formy współpracy dwunastu państw, "Sprawy Międzynarodowe” 2019, no. 72, p. 135.

31 J. M. Nowakowski, Trójmorze czy Międzymorze, Warsaw 2020, p. 12.

32 K. Popławski, J. Jakóbowski, W kierunku budowy bliższych powiązań Trójmorze jako obszar gospodarczy, Warsaw 2020, p. 9.

${ }_{33}$ Polska i Rumunia wobec aktualnych wyzwań w regionie, https://sejm.gov.pl/, access 15 VI 2021. 
100 largest companies from the Visegrad Group countries as well as Croatia, Slovenia and Romania.

Concurrently, from the Polish point of view, Romania is the most attractive market for economic cooperation. This is visible in the constantly growing trade exchange rates. As for the Polish side, Romania is indicated as having great potential for growth and willingness to cooperate with Polish investors. Threats to Polish investments are poor infrastructure and deficiencies in state administration ${ }^{34}$. However, already now some segments of the Polish economy are doing very well on the Romanian market, e.g. in computer services (EUR 14 million) ${ }^{35}$.

The 3SI is facing many challenges with Romania and Poland being the axis of main strategic actions. Both countries are in favor of increasing the role of the US and NATO on the eastern flank. They draw attention to the Russian threat. For Poland, are noted the further militarization of the Kaliningrad region, the dependence of Austria's banking sector on Russian contractors, the reliance on the Russians to build a nuclear power plant in Hungary, unrest and disinformation activities among the Baltic states, and the deployment of permanent Russian forces in Belarus. Romania, in turn, points to the proRussian attitude of Bulgarian society, the escalation of conflict in the Black Sea basin (Ukraine, Georgia); it is also concerned about the deployment of Russian troops in Serbia and Transdniestria ${ }^{36}$, as well as the proposals of cooperation with Russia made by certain NATO countries (Turkey) ${ }^{37}$. Notably, Romania and the Czech Republic are supporting Poland at the EU forum on the issue of sanctions against Russia for the construction of Nord Stream $2^{38}$. The 3 SI has the potential to become a platform not only for cooperation, but also for security, initially in the economic and cyber security pillars, and later to expand the extent of cooperation within a broader spectrum of activities.

Romania embarked on a sharp course against Russia. The National Security Strategy refers several times to Russia as the main threat in the CEE area; a novelty. Romania is also concerned about the growth of hybrid threats and the militarization of the Black Sea, as well as the increasing military presence of Russia in its neighborhood ${ }^{39}$. Security issues are a key factor binding the Polish and Romanian sides. Both countries are striving to elaborate 3SI structures, capable of constituting a security platform, or at least translating into an increase of the geo-economic potential of the region.

As for cyber security, discussions between the Prime Minister of Poland and the Prime Minister of Romania on the siting of the European Centre of Competence were underway. The parties specified the greatest threat to the security of the eastern

${ }^{34}$ Mapa rynków eksportowych, http://www.mapa.kuke.com.pl/rumunia.html, access 15 VI 2021.

35 I. Albrycht, Europejski rynek cyberbezpieczeństwa. Potencjał regionu Trójmorza, Kraków 2018, p. 36.

36 K. Rumiński, Japonia wobec Trójmorza - perspektywy współpracy, Warsaw 2021, p. 26.

37 P. Stepper, K. Kozma, The complexity of NATO's Southeast European defense, "The Bellona Quarterly" 2020, 703 .

38 W. Jakóbik, Gazprom chce uruchomić Nord Stream 2 do końca roku, a nowe sankcje nie nadchodza, https://biznesalert.pl/, access 15 VI 2021.

39 K. Całus, op. cit. 
flank as well as the entire EU are cyberattacks. The dependence of state and military infrastructure on digital solutions leads to an increase in IT challenges ${ }^{40}$.

This is further augmented by the Sino-American rivalry in the CEE area in terms of new technologies. As a region plainly open to cooperation with the U.S. (with the exception of Hungary, which is strongly cooperating with China on 5G), the 3SI is part of an international strategy to build and maintain a unilateral world order. 5G is one of the strategic investments of the United States, which wants to use this technology to control the flow of information in the block of allied countries and in parallel eradicate the Chinese threat ${ }^{41}$. Romania and Poland are engaging with US Big Tech companies (Google, Amazon, Facebook, Apple, Microsoft) to build national information and cyber security strategies. Both countries are aware of the information mapping capabilities and are therefore pursuing a two-pronged approach: To strengthen autonomous cyber structures and to enhance cooperation with the U.S. ${ }^{42}$.

Poland and Romania are seeking greater U.S. involvement in the 3SI. For Romania, there are vested interests at stake, a case in point being the meeting between NicolaeIonel Ciucă and the U.S. ambassador and chairwoman of Eximbank. Romania seeks to step up its cooperation with the US in multiple fields at once: defense, economy, and technology. Here, it particularly seeks to leverage the 3 SI format ${ }^{43}$.

Romania and Poland are both seeking to make the 3SI an area of geostrategic importance, balancing the geopolitics of the world's powers with the opportunity to reap the greatest possible benefits for the countries in this region, mainly in the area of security. Romania has signed an agreement with the U.S. to form a consortium for the construction of two new reactors at the Cernavodă Power Plant ${ }^{44}$. In doing so, Romania opted out of cooperation with China. Talks with the Chinese had been ongoing since 2013, but eventually Bucharest yielded to US pressure ${ }^{45}$. Poland and Romania are aware that the territories of their countries have been turned into a battleground for international games. In both cases, they seek to profit as much as possible from the favorable international situation.

Romania and Poland are the gateways for the US to the entire region of Central and Eastern Europe. For the US, the 3SI is one of the instruments of political influence wielded through economic and technological measures. The location of the 3SI, including Romania and Poland, is of key importance in this regard, as investments in

40 P. Müller, Rozmowa telefoniczna premierów Polski i Rumunii, https://www.gov.pl/, access 15 VI 2021.

${ }_{41}$ P. Grochmalski, P. Lewandowski, P. Paszak, op. cit.

42 P. Grochmalski, US-China rivalry for strategic domination in the area of artificial intelligence and the new AI geopolitics, "The Bellona Quarterly" 2020, 701, pp. 5-25.

${ }_{43}$ W. Jakóbik, Atom z USA może zamienić Polskę i Trójmorze w plac budowy, https://biznesalert.pl/, access 15 VI 2021.

44 Rumunia i USA podpisały projekt umowy w sprawie nowych reaktorów, https://www.cire.pl/, access 15 VI 2021.

45 K. Całus, J. Jakóbowski, Rumunia: koniec wspótpracy z Chinami w sektorze jądrowym, https://www. osw.waw.pl/, access 15 VI 2021. 
both countries allow the Americans to exert influence not only on China or Russia, but also on other regions (e.g. the Middle East, or the Caucasus).

Poland and Romania also share common projects under the 3SI. For Romania, the complementary infrastructure solutions of the project, Via Carpatia and Rail2Sea ${ }^{46}$, have been of great importance. Both projects will facilitate increased trade and lifting of existing infrastructural barriers. For Romania and Poland, the projects are of the utmost relevance as they facilitate further growth of cooperation between the countries on the North-South axis. The largest part of the construction costs will be covered by Poland and Romania. In general, the general outline of the entire 3SI is to improve cooperation of the CEE states, in particular with regard to the meridian cooperation.

Poland's hopes are high for the development of an energy alternative offered by Romania's gas resources on the Black Sea coast. Romania is one of the least hydrocarbon importer countries. With increased extraction of undersea fields, Romania stands to become a 3SI southern gas hub. Romania along with its fields and the construction of terminals in Świnoujście and on Krk Island will lead to a strong diversification of supplies from Russia through the construction of the "North-South Corridor" and Eastring ${ }^{47}$. This will strengthen Romania' s position in the region, in the whole 3SI, and thus in the international security environment.

For Poland and Romania, the 3SI format is also seen as a way to tackle the vital issues faced by the two countries. First of all, the challenges that Romania is facing and that the 3SI format can help with are the highest-in-the-EU percentage of population living out-of-state, reaching $18 \%{ }^{48}$.

Romania has one of the lowest innovation rates in the EU. Yet, on a global scale, Romania and the 3SI states perform quite well ${ }^{49}$. Romania also has one of the lowest $\mathrm{R} \& \mathrm{D}$ expenditures in Europe, a low percentage of people employed in creative industries including ICT $1.9 \%{ }^{50}$. Therefore, infrastructure and particularly cybersecurity projects within the 3SI stand a chance to boost the level of technological progress of the entire region by building their own solutions in $5 \mathrm{G}$ networks, Internet of Things, Artificial Intelligence, or Cyber Security. Romania does appear to recognize that the IT sector will be the strategic one in the near future ${ }^{51}$.

46 România-SUA: Optimizarea mobilității militare NATO și securitatea energetică, http://presamil.ro/, access 15 VI 2021.

47 M. Paszkowski, W poszukiwaniu prymusa: postępy w realizacji projektów energetycznych państw Inicjatywy Trójmorza, Komentarze IEŚ, 2020, no. 271.

48 K. Popławski, J. Jakóbowski, op. cit., p. 21.

49 I. Albrycht, op. cit., p. 29.

50 Ibidem, p. 32.

51 R. Lupitu, Inițiativa celor Trei Mări: Klaus Iohannis și omologii săi din Europa Centrală și de Est se reunesc, luni, într-un summit virtual la care participă și președintele Germaniei și secretarul de stat al SUA, https://www.caleaeu-ropeana.ro/, access 15 VI 2021. 


\section{Conclusions}

Poland recognizes Romania as one of the leaders of the CEE countries and thus of the 3SI format. Romania, Poland and Croatia are leaders of the initiative, as evidenced by the first summits, Dubrovnik 2016, Warsaw 2017, and Bucharest 2018. The most resounding summit was hosted by Romania, as they saw chances in the 3SI to strengthen their international status. Romania's engagement in the 3SI allowed for the evolution and slow institutionalization of the format, e.g. through the 3SI Fund.

Romania incorporates its presence in the 3SI at different levels of the international security strategy. Mainly, this is reflected by promoting the idea of transatlantic cooperation and the US military presence in the region, for which it attempts to harness both the 3SI, the B9, and NATO structures.

Romania's leadership position is underscored by the Polish party. There are many common and coherent visions for the development of the 3SI as far as the postulated Warsaw-Bucharest axis is concerned. The overlap in Poland's and Romania's view of the 3SI is expressed, for instance, in its economic and infrastructural nature. This concerns mainly the communication infrastructure, through which both states, as transit countries, gain geopolitical importance in vertical and horizontal arrangements. Likewise, it is the case with energy infrastructure, where Romania is portrayed as an energy hub with its Black Sea resources. With the 3SI and the improvement of its image in the EU, Romania looks forward to and has a chance to become a member of the Schengen area.

Poland and Romania are strengthening their economic cooperation. Joint infrastructure projects will improve political relations. There are a number of reasons to believe that in the future, if the existing course and climate of cooperation are preserved, both countries will become leaders of the CEE region, in which the 3SI format will become a plane for advancing the common interests of all the states in the region.

\section{$\sim$}

Abstract: The article discusses the issue of Romania's place and role in the Three Seas Initiative. The text introduces the Polish view of cooperation with reference to the common objectives of both countries and the Community concepts of security policy development in Central and Eastern Europe. The paper discusses the idea of the Three Seas Initiative, illustrates its place in Romania' s foreign policy and security strategy, as well as examines the potential for Polish-Romanian cooperation in the Three Seas Initiative, indicating common grounds required for partnership and leadership of both countries in the Three Seas Initiative region.

Keywords: Three Seas Initiative, Romania, Romanian foreign policy, Polish foreign policy, geopolitics of Central and Eastern Europe, international security 
Pobrane z czasopisma Wschód Europy http://journals.umcs.pl/we

Data: 26/04/2023 16:40:34

The Warsaw-Bucharest axis and Romania's place in the Three Seas Initiative...

\title{
Oś Warszawa-Bukareszt i miejsce Rumunii w inicjatywie Trójmorza? Polsko-rumuńskie przywództwo w inicjatywie Trójmorza (3SI)
}

Streszczenie: Artykuł porusza kwestię miejsca i roli Rumunii w Inicjatywie Trójmorza. Tekst wprowadza polskie spojrzenie na współpracę w odniesieniu do wspólnych celów obu krajów oraz wspólnotowych koncepcji rozwoju polityki bezpieczeństwa w Europie Środkowo-Wschodniej. Artykuł omawia ideę Inicjatywy Trójmorza, ilustruje jej miejsce w rumuńskiej polityce zagranicznej i strategii bezpieczeństwa, a także analizuje potencjał polsko-rumuńskiej współpracy w ramach Inicjatywy Trójmorza, wskazując wspólne podstawy potrzebne do partnerstwa i przywództwa oba kraje w regionie Inicjatywy Trójmorza.

Słowa kluczowe: Inicjatywa Trójmorza, Rumunia, rumuńska polityka zagraniczna, polska polityka zagraniczna, geopolityka Europy Środkowo-Wschodniej, bezpieczeństwo międzynarodowe

\section{Ось Варшава-Бухарест и место Румынии в Инициативе трех морей? Польско- румынское лидерство в Инициативе трех морей (3SI)}

\begin{abstract}
Аннотация: В статье обсуждается место и роль Румынии в Инициативе трех морей. Текст представляет польский взгляд на сотрудничество в отношении общих целей обеих стран и концепции Сообщества по развитию политики безопасности в Центральной и Восточной Европе. В статье обсуждается идея инициативы трех морей, показано ее место во внешней политике и стратегии безопасности Румынии, а также анализируется потенциал польско-румынского сотрудничества в рамках инициативы трех морей, указывая на общие основы, необходимые для партнерства и лидерства обеих сторон. страны региона Инициативы трех морей.
\end{abstract}

Ключевые слова: инициатива трех морей, Румыния, внешняя политика Румынии, внешняя политика Польши, геополитика Центральной и Восточной Европы, международная безопасность

\section{Bibliography}

Albrycht I., Europejski rynek cyberbezpieczeństwa. Potencjat regionu Trójmorza, Kraków 2018.

Chodakiewicz M. J., Międzymorze, Warsaw 2016.

Dobija M., Geopolityczne czynniki innowacyjnego rozwoju Polski i krajów Trójmorza, "Nierówności Społeczne a Wzrost Gospodarczy" 2019, no. 59. DOl: https://doi.org/10.15584/nsawg.2019.3.3.

Grochmalski P., Lewandowski, Paszak P., US-China Technological Rivalry and its Implications for the Three Seas Initiative (3SI), "European Research Studies Journal" 2020, Special no. 2. DOI: https:// doi.org/10.35808/ersj/1901.

Grochmalski, US-China rivalry for strategic domination in the area of artificial intelligence and the new Al geopolitics, "The Bellona Quarterly" 2020, no. 701. DOI: https://doi.org/10.5604/01.3001.0014.3837. Henning K., Inicjatywa Trójmorza. Jeśli razem, to dokąd i jak?, Kraków 2018.

Kotulewicz-Wisińska K., Stosunki polsko-rumuńskie w latach 2009-2017. Wybrane problemy, "Krakowskie Studia Małopolskie" 2018, no. 23. DOl: https://doi.org/10.15804/ksm201807.

Kowal P., Orzelska-Stączek A., Inicjatywa Trójmorza: geneza, cele i funkcjonowanie, Warsaw 2019.

Lewandowski P., Geopolitical Ideas of Great Space as Soft Power - Analysis of the Case of the Republic of Poland, "The Bellona Quarterly" 2019, no. 698/3. DOl: https://doi.org/10.5604/01.3001.0013.7448. 
Lewandowski P., Soft power Rzeczypospolitej w Inicjatywie Trójmorza, "Sprawy Międzynarodowe" 2020, no. 73(2). DOl: https://doi.org/10.35757/SM.2020.73.2.01.

Milewski 0., Trójmorze - nowy instrument w polskiej polityce zagranicznej, "Polski Przegląd Dyplomatyczny" 2017, no. 4.

Mróz M., Wielki projekt małych krajów. Od Międzymorza do Trójmorza w polityce zagranicznej Polski w dobie drugiego rządu Prawa i Sprawiedliwości, "Dyplomacja i bezpieczeństwo” 2018, no. 5.

Nierada P., Dokąd zmierza Trójmorze? "Układ Sił" 2020, no. 23.

Nowakowski J. M., Trójmorze czy Międzymorze, Warsaw 2020. DOl: https://doi.org/10.33226/00326186.2020.8.2.

Orzelska-Stączek A., Inicjatywa Trójmorza w świetle teorii realizmu. Polityczne aspekty nowej formy współpracy dwunastu państw, "Sprawy Międzynarodowe" 2019, no. 72. DOl: https://doi.org/10.35757/ SM.2019.72.1.07.

Paszkowski M., W poszukiwaniu prymusa: postępy w realizacji projektów energetycznych państw Inicjatywy Trójmorza, Komentarze IEŚ, 2020, no. 271.

Pieńkowski J., Polityka europejska Rumunii, "Biuletyn Polskiego Instytutu Spraw Międzynarodowych" 2017, no. 99.

Popławski K., Jakóbowski J., W kierunku budowy bliższych powiązań Trójmorze jako obszar gospodarczy, Warsaw 2020.

Rumiński K., Japonia wobec Trójmorza - perspektywy współpracy, Warsaw 2021, p. 26.

Skrzeszewska M., Droga Serbii do Unii Europejskiej - stan i perspektywy, "Studia Europejskie" 2016, no. 1.

Stepper P., Kozma K., The complexity of NATO's Southeast European defense, "The Bellona Quarterly" 2020. DOI: https://doi.org/10.5604/01.3001.0014.6982.

Surmacz B., Dyplomacja na szczycie, "TEKA of Political Science and International Relations" 2016, no. 11/3. DOl: https://doi.org/10.17951/teka.2016.11.3.95.

Sykulski L., Trójmorze w świecie wielobiegunowym, "Myśl suwerenna. Przegląd spraw publicznych" 2020, no. 2.

Ukielski P., Inicjatywa Trójmorza w polskiej polityce zagranicznej, "Studia Europejskie" 2018, no. 2.

Ukielski P., Mapa Trójmorza. Przegląd punktów wspólnych i rozbieżności w polityce 12 państw regionu, "Raport" 2016, no. 3.

Zubelewicz K., Polska, "Europa Środkowo-Wschodnia" 2012, no. 19.

\author{
Netography \\ http://presamil.ro/ \\ http://three-seas.eu/ \\ http://www.mae.ro/ \\ http://www.mapa.kuke.com.pl/ \\ https://biznesalert.pl/ \\ https://danube-region.eu/ \\ https://energetyka24.com/ \\ https://pism.pl/ \\ https://sejm.gov.pl/ \\ https://www.caleaeu-ropeana.ro/
}


Pobrane z czasopisma Wschód Europy http://journals.umcs.pl/we

Data: 26/04/2023 16:40:34

The Warsaw-Bucharest axis and Romania' s place in the Three Seas Initiative...

https://www.cire.pl/

https://www.gov.pl/

https://www.osw.waw.pl/

https://www.prezydent.pl/ 